\title{
KESALAHAN PENGGUNAAN EJAAN BAHASA INDONESIA (EBI) \\ PADA KARYA ILMIAH MAHASISWA
}

\author{
Lilis Amaliah Rosdiana
}

Universitas Winaya Mukti Bandung

lilisamaliah87@gmail.com

\begin{abstract}
ABSTRAK
Penelitian ini mempunyai tujuan untuk mendeskripsikan kesalahan penggunaan Ejaan Bahasa Indonesia (EBI) dalam karya ilmiah mahasiswa Fakultas Pertanian Universitas Winaya Mukti. Karya ilmiah yang diambil yaitu berupa makalah. Metode penelitian yang digunakan adalah penelitian deskriptif. Objek penelitian ini adalah analisis kesalahan penggunaan EBI dalam karya ilmiah mahasiswa. Metode pengumpulan data yang digunakan yaitu metode simak dengan teknik lanjutan catat. Karena dalam penelitian ini berupa data tertulis, maka metode simak dilakukan dengan cara membaca seksama yang kemudian diikuti dengan teknik catat untuk mengklasifikasi data yang relevan. Data diambil dari kesalahan EBI mahasiswa di bagian latar belakang penelitian yang ditemukan pada kertas mereka. Hasil yang didapat menunjukan bahwa di dalam latar belakang penelitian karya tulis mahasiswa, peneliti menemukan beberapa kesalahan penggunaan EBI di antaranya: pemakaian huruf; penulisan kata (kata dasar, kata berimbuhan, dan kata depan); dan penggunaan tanda baca.
\end{abstract}

Kata kunci: kesalahan, Ejaan Bahasa Indonesia (EBI), karya tulis mahasiswa.

\begin{abstract}
ABSTRACK
This research to describes the use of Ejaan Bahasa Indonesia (EBI) in the paper by students of Agriculture of Winaya Mukti University. The research object is analysis the mistake of EBI in students paper. The data was taken from university student EBI mistake in backround of the study found in their paper. This study belongs to descriptive qualitative. The result of the analysis denote which includes punctuations, mistake in making of italic words, capital words, prefix, mistyping of some words, and some mistake in spelling.
\end{abstract}

Key words: mistake, Ejaan Bahasa Indonesia (EBI), students paper.

How to Cite:

Lilis Amaliah Rosdiana. (2020). KESALAHAN PENGGUNAAN EJAAN BAHASA INDONESIA (EBI) PADA KARYA ILMIAH MAHASISWA. Bahtera Indonesia; Jurnal Penelitian Bahasa Dan Sastra Indonesia,5(1), 1-11. https://doi.org/10.31943/bi.v5i1.58

DOI: https://doi.org/10.31943/bi.v5i1.58 


\section{PENDAHULUAN}

Tussolekha (2019) mengatakan bahwa analisis kesalahan dalam penggunaan Ejaan Bahasa Indonesia (EBI) merupakan kesalahan dalam penggunaan atau pemakaian bahasa yang sesuai dengan kaidah Bahasa yang disusun oleh Pusat Pengembangan dan Perlindungan, Badan Pengembangan dan Pembinaan Bahasa.

Sejalan dengan pendapat di atas, menurut Safriandi dalam Fajarya (2016) kesalahan berbahasa Indonesia adalah pemakaian bentuk-bentuk tuturan berbagai unit kebahasaan yang meliputi kata, kalimat, paragraf, yang menyimpang dari sistem kaidah Bahasa Indonesia baku, serta pemakaian ejaan dan tanda baca yang menyimpang dari sistem ejaan dan tanda baca yang telah ditetapkan dalam buku Pedoman Umum Ejaan Bahasa Indonesia (PUEBI).

Ejaan merupakan kaidah yang harus dipatuhi oleh pemakai bahasa demi keteraturan dan keseragaman bentuk, terutama dalam bahasa tulis. Keteraturan bentuk akan berimplikasi pada ketepatan dan kejelasan makna. Ini bertujuan agar si pembaca dapat mengerti dengan utuh dan memahami makna yang ingin disampaikan si penulis.
Kemampuan menulis mahasiswa di perguruan tinggi seharusnya sudah tidak diragukan lagi. Kemampuan menulis adalah merupakan modal penting bagi mahasiswa, dengan menulis baik yang berkaitan dengan tugas akademik ataupun berkaitan dengan masyarakat. Mahasiswa dituntut untuk mampu menulis dengan baik dan benar karena mereka akan dituntut untuk menulis karya-karya ilmiah seperti menulis artikel, makalah, jurnal, dan skripsi.

Makalah merupakan salah satu bentuk karya ilmiah. Mahasiswa harus mempunyai keterampilan menulis yang baik agar dapat menghasilkan makalah yang baik. Salah satu keterampilan yang harus dimiliki mahasiswa yaitu penguasaan keterampilan berbahasa yang meliputi penguasaan ejaan dan tanda baca, penguasaan pembentukan dan pemilihan kata, penguasaan kalimat efektif dan juga penguasaan paragraf yang utuh.

Namun pada kenyataannya, masih banyak mahasiswa yang melakukan kesalahan-kesalahan ejaan dalam penulisan makalahnya. Mereka kurang memerhatikan bahwa kesalahan sedikit saja bisa menimbulkan multitafsir pembaca makalah tersebut.

Kesalahan-kesalahan tersebut sering dianggap kesalahan umum yang banyak 
terjadi pada makalah-makalah mata kuliah lain yang seharusnya tidak boleh disepelekan.

Kemampuan menulis mahasiswa di perguruan tinggi seharusnya sudah tidak diragukan lagi. Kemampuan menulis adalah merupakan modal penting bagi mahasiswa, dengan menulis baik yang berkaitan dengan tugas akademik ataupun berkaitan dengan masyarakat. Mahasiswa dituntut untuk mampu menulis dengan baik dan benar karena mereka akan dituntut untuk menulis karya-karya ilmiah seperti menulis artikel, makalah, jurnal, dan skripsi.

Makalah merupakan salah satu bentuk karya ilmiah. Mahasiswa harus mempunyai keterampilan menulis yang baik agar dapat menghasilkan makalah yang baik. Salah satu keterampilan yang harus dimiliki mahasiswa yaitu penguasaan keterampilan berbahasa yang meliputi penguasaan ejaan dan tanda baca, penguasaan pembentukan dan pemilihan kata, penguasaan kalimat efektif dan juga penguasaan paragraf yang utuh.

Namun pada kenyataannya, masih banyak mahasiswa yang melakukan kesalahan-kesalahan ejaan dalam penulisan makalahnya. Mereka kurang memerhatikan bahwa kesalahan sedikit saja bisa menimbulkan multitafsir pembaca makalah tersebut.
Kesalahan-kesalahan tersebut sering dianggap kesalahan umum yang banyak terjadi pada makalah-makalah mata kuliah lain yang seharusnya tidak boleh disepelekan.

\section{METODOLOGI PENELITIAN}

Penelitian ini menggunakan penelitian deskriptif. Menurut Sugiyono (2013) penelitian deskriptif adalah penelitian yang dilakukan untuk mengetahui nilai variabel mandiri, baik satu variabel atau lebih (independen) tanpa membuat perbandingan, atau menghubungkan dengan variabel yang lain.

Objek penelitian yang digunakan dalam penelitian ini karya tulis mahasiswa berupa makalah pada bagian latar belakang. Metode pengumpulan data yang digunakan dalam penelitian ini yaitu metode simak dengan teknik lanjutan catat. Karena dalam penelitian ini berupa data tertulis, maka metode simak dilakukan dengan cara membaca seksama yang kemudian diikuti dengan teknik catat untuk mengklasifikasi data yang relevan.

Sebagai langkah analisis data, pada penelitian ini penulis menggunakan pendekatan kualitatif dengan teknik analisis deskriptif. Pada proses selanjutnya, metode deskriptif diterapkan sebagai usaha memberikan gambaran atau menguraikan sasaran penelitian, 
Data penelitian berupa Bahasa tulisan yang mengandung kesalahan Ejaan Bahasa Indonesia (EBI) pada bagian latar belakang makalah mahasiswa Program Studi Agribisnis S1 angkatan 2018 Fakultas buku.

Pertanian Universitas Winaya Mukti. Makalah yang dijadikan sumber data sebanyak 25 buah.

\section{HASIL DAN PEMBAHASAN}

Berdasarkan penelitian telah yang dilakukan, peneliti menemukan banyak kesalahan EBI yang dilakukan oleh mahasiswa. Kesalahan-kesalahan tersebut peneliti uraikan sebagai berikut:

Jenis-jenis Kesalahan Penggunaan Ejaan

\section{Bahasa Indonesia}

Dalam penelitian ini banyak sekali ditemukan kesalahan penggunaan ejaan. Ini terlihat pada kesalahan pemakaian tanda baca, pemakaian huruf, dan penulisan kata.

\section{Kesalahan Pemakaian Huruf}

Peneliti menemukan sebanyak 108 data pada bagian kesalahan pemakaian huruf ini. Kesalahan pemakaian huruf yang ditemukan adalah kesalahan yang berhubungan dengan hal-hal berikut.

\section{a. Kesalahan Pemakaian Huruf Kapital}

Peneliti menemukan ada 86 data kesalahan pemakaian huruf kapital ini.
Mahasiswa tidak menggunakan huruf kapital di antaranya ada pada penulisan awal kalimat, huruf pertama nama bulan, huruf pertama nama geografi, dan huruf pertama nama judul

Berikut ini adalah beberapa contoh kesalahan pemakaian huruf tersebut.

(1) kecap adalah bumbu yang terbuat dari biji kedelai hitam.

(2) Tingkat pengangguran di jakarta meningkat dari $17,20 \%$ pada bulan $\underline{\text { agustus }}$ tahun 2000 menjadi $19,14 \%$ pada tahun agustus 2001.

(3) hidroponik adalah sistem budidaya yang menggunakan air sebagai media utamanya.

(4) Menurut Hanafiah dalam bukunya yang berjudul sawi dan selada, tanaman sawi dapat tumbuh....

(5) petani banyak melakukan kebiasaan membakar jerami.

Berikut merupakan perbaikan atas kesalahan tersebut.

(1a) Kecap adalah bumbu yang terbuat dari biji kedelai hitam.

(2a) Tingkat pengangguran di Jakarta meningkat dari $17,20 \%$ pada bulan Agustus tahun 2000 menjadi 19,14\% pada tahun Agustus 2001. 
(3a) Hidroponik adalah sistem budidaya yang menggunakan air sebagai media utamanya.

(4a) Menurut Hanafiah dalam bukunya yang berjudul Sawi dan Selada, tanaman sawi dapat tumbuh....

(5a) Petani banyak melakukan kebiasaan membakar jerami.

\section{b. Kesalahan Pemakaian Huruf Miring}

Peneliti menemukan 22 data kesalahan pada pemakaian huruf miring. Mahasiswa tidak menggunakan huruf miring pada penulisan nama ilmiah atau kata-kata yang bersasal dari bahasa asing.

Berikut peneliti sajikan beberapa contoh kesalahan pemakaian huruf miring.

(6) Tanaman sawi (Brassica rapa var.) merupakan salah satu tanaman sayur yang sangat mudah dikembangkan.

(7) Subsistem budidaya (on farm) merupakan subsistem yang penting dari sistem dan usaha agribisnis.

(8) Wereng hijau (Nephotteix virescens) berperan sebagai vector dari virus tungro padi ( rice tungo virus).

(9) Sweet corn adalah merupakan salah satu varietas yang relative baru yang dikembangkan di Indonesia.
(10) ... pertumbuhan dan hasil tanaman jagung manis kultivar Sweet Corn Thailand.

Berikut merupakan perbaikan atas kesalahan tersebut.

(6b) Tanaman sawi (Brassica rapa var.) merupakan salah satu tanaman sayur yang sangat mudah dikembangkan.

(7b) Subsistem budidaya (on farm) merupakan subsistem yang penting dari sistem dan usaha agribisnis.

(8b) Wereng hijau (Nephotteix virescens) berperan sebagai vector dari virus tungro padi (rice tungo virus).

(9b) Sweet corn adalah merupakan salah satu varietas yang relatif baru yang dikembangkan di Indonesia.

(10b) ... pertumbuhan dan hasil tanaman jagung manis kultivar Sweet Corn Thailand.

\section{Kesalahan Penulisan Kata}

\section{a. Penulisan Kata Dasar}

Peneliti menemukan ada 130 data kesalahan. Ini adalah kesalahan terbanyak di antara kesalahan lainnya. Mahasiswa banyak melakukan kesalahan penulisan kata dasar, ini bisa dengan kurangnya huruf abjad pada sebuah kata atau bisa juga adanya huruf abjad 
yang tak seharusnya berada pada kata tersebut.

Berikut adalah beberapa contoh kesalahan penulisan kata pada penulisan kata dasar.

(11) Saat ini banyak dilakuakan untuk menghasilkan bahan makanan yang aman serta bebas dari bahan-bahan kimia.

(12) Ketersediaan hasi produksi padi baik dari segi kuntitas maupun kualitas sangat dibutuhkan untuk memenuhi....

(13) ... meningkatnya minat masyrakat terhadap obat-obatan yan terbuat dari bahan alami ....

(14) Indinesia memiliki kurang lebih 7.000 spesies tanaman obat.

(15) Pupuk kandang domba sebagai pupuk organik akan memberikan pengaruh dalam meningkatkatn kualitas tanah....

Berikut merupakan perbaikan atas kesalahan tersebut.

(11a) Saat ini banyak dilakukan untuk menghasilkan bahan makanan yang aman serta bebas dari bahan-bahan kimia. (12a) Ketersediaan hasil produksi padi baik dari segi kuantitas maupun kualitas sangat dibutuhkan untuk memenuhi....

(13a) ... meningkatnya minat masyarakat terhadap obat-obatan yang terbuat dari bahan alami ....

(14a) Indonesia memiliki kurang lebih 7.000 spesies tanaman obat.

(15a) Pupuk kandang domba sebagai pupuk organik akan memberikan pengaruh dalam meningkatkan kualitas tanah....

\section{b. Pemakaian Kata Berimbuhan}

Peneliti menemukan 46 data kesalahan dalam hal kata berimbuhan karena tidak menuliskan serangkaian kata dasar yang mendapatkan imbuhan berupa awalan, sisipan, dan atau akhiran. Berikut ini adalah beberapa contoh data kesalahan pemakaian kata berimbuhan.

(16) ...untuk menambah unsur hara $\mathrm{N}, \mathrm{P}$, dan K perlu di berikan pupuk anorganik.

(17) ... sejenis tanaman budidaya dan palawija yang di kenal luas di daerah tropis.

(18) ... dapat dengan mudah di serap oleh perakaran tanaman. 
(19) ... untuk mengetahui gambaran usaha ternak sapi perah di lihat dari aspek penyediaan....

(20) Hasil tanaman bayam di pengaruhi oleh pertumbuhan tanaman ....

Berikut merupakan perbaikan atas kesalahan tersebut.

(16b) ...untuk menambah unsur hara N, P, dan K perlu diberikan pupuk anorganik.

(17b) ... sejenis tanaman budidaya dan palawija yang dikenal luas di daerah tropis.

(18b) ... dapat dengan mudah diserap oleh perakaran tanaman.

(19b) ... untuk mengetahui gambaran usaha ternak sapi perah dilihat dari aspek penyediaan....

(20b) Hasil tanaman bayam dipengaruhi oleh pertumbuhan tanaman ....

\section{c. Kesalahan Pemakaian Kata Depan}

Peneliti menemukan kesalahan penulisan kata depan di. Terdapat 16 data kesalahan pada pemakaian kata depan ini. Mahasiswa banyak melakukan kesalahan dengan menuliskan kata depan di secara tidak terpisah dari kata yang mengikutinya.

Berikut adalah beberapa contoh kesalahan pemakaian kata depan di.
(21) Sebelum dilakukan penanaman dilahan, tanaman diuji daya kecambahnya terlebih dahulu menggunakan....

(22) Tanaman sayuran merupakan sumber hara makro yang baik yang baik, namun petani didaerah penelitian belum dapat....

(23) ... tanaman hias dan jarang sekali ditemukan dengan tanaman budidaya yang ada dilahan pertanian....

(24) ... bertanam sayuran dipot dan jika kita didataran rendah....

(25) ... didalam penelitian ini, peneliti ingin memanfaatkan limbah baglog jarum tiram....

Berikut merupakan perbaikan atas kesalahan tersebut.

(21c) Sebelum dilakukan penanaman $\boldsymbol{d i}$ lahan, tanaman diuji daya kecambahnya terlebih dahulu menggunakan....

(22c) Tanaman sayuran merupakan sumber hara makro yang baik yang baik, namun petani di daerah penelitian belum dapat....

(23c) ... tanaman hias dan jarang sekali ditemukan dengan tanaman budidaya yang ada di lahan pertanian.... 
(24c) ... bertanam sayuran di pot dan jika kita didataran rendah....

(25c) ... di dalam penelitian ini, peneliti ingin memanfaatkan limbah baglog jarum tiram....

\section{Kesalahan Pemakaian Tanda Baca}

Kesalahan pemakaian tanda baca yang ditemukan sebanyak 74 data. Kesalahan ini meliputi kesalahan pemakaian tanda titik (.) dan tanda koma (,).

\section{a. Kesalahan Pemakaian Tanda Titik (.)}

Dalam hal pemakaian tanda titik, ditemukan sebanyak 43 data kesalahan. Kesalahan ini terjadi karena penulis tidak membubuhkan tanda titik pada akhir kalimat pernyataan.

Berikut ini beberapa contoh data yang menunjukan kesalahan jenis tersebut.

(26) Saat ini dunia pertanian semakin luas seiring dengan perkembangan teknologi yang semakin canggih

(27) Pupuk organik adalah pupuk yang berasal dari bahan alami yang merupakan sisa makhluk hidup

Berikut ini merupakan perbaikan datadata tersebut. (26a) Saat ini dunia pertanian semakin luas seiring dengan perkembangan teknologi yang semakin canggih.

(27a) Pupuk organik adalah pupuk yang berasal dari bahan alami yang merupakan sisa makhluk hidup.

\section{b. Kesalahan Pemakaian Tanda Koma (,)}

Kesalahan pemakaian tanda baca koma (,) dalam penelitian ini ditemukan sebanyak 31 data kesalahan. Kesalahan pemakaian tanda baca koma terjadi karena penulis melakukan hal-hal berikut.

1) Tanda koma tidak dipakai di antara unsur-unsur suatu perincian (18 data kesalahan).

2) Tanda koma tidak dipakai untuk memisahkan anak kalimat dari induk kalimat, jika anak kalimat itu mendahului induk kalimat (7 data).

3) Tanda koma tidak dipakai di belakang kata atau ungkapan penghubung antarkalimat yang berada di awal kalimat (6 data kesalahan).

Berikut adalah beberapa contoh kesalahan pemakaian tanda koma.

(28) ... unsur hara tanah di samping menjaga sifat fisik, biologi_dan kimia tanah.

(29) ... contohnya seperti sate, semur jengkol, tumis kangkung, tempe goreng_dan sambal terasi. 
BAHTERA INDONESIA:

ISSN 2541-3252

Jurnal Penelitian Pendidikan Bahasa dan Sastra Indonesia

Vol. 5, No. 1, Mar. 2020

(30) Susu ini mengandung protein,

karbohidrat_dan lemak.

\begin{tabular}{|c|c|c|c|c|c|c|}
\hline No & $\begin{array}{l}\text { Kode } \\
\text { Mak } \\
\text { alah }\end{array}$ & $\begin{array}{c}\text { Pemak } \\
\text { aian } \\
\text { Tanda } \\
\text { Baca }\end{array}$ & $\begin{array}{c}\text { Pemakai } \\
\text { an } \\
\text { Huruf }\end{array}$ & $\begin{array}{c}\text { Penuli } \\
\text { san } \\
\text { Kata }\end{array}$ & Jumlah & $\begin{array}{c}\text { Persent } \\
\text { ase }\end{array}$ \\
\hline
\end{tabular}

(31) Jika ragi tersebut bagus_tempe akan 1 NSR menjadi sangat enak.

$2 \mathrm{NN}$

(32) Jadi_dari uraian di atas, penulis merumuskan masalah sebagai berikut.

Berikut ini merupakan perbaikan data- $6 \quad$ DLJ

data tersebut.

... unsur hara tanah di samping menjaga sifat fisik, biologi, dan kimia tanah.

$(29 b)$ ... contohnya seperti sate, semur 12 MYF jengkol, tumis kangkung, tempe 13 MZ goreng, dan sambal terasi.

(30b) Susu ini mengandung protein, karbohidrat, dan lemak.

(31b) Jika ragi tersebut bagus, tempe akan menjadi sangat enak.

$\begin{array}{lllllll}14 & \text { MFZ } & 3 & 6 & 14 & 23 & 6,15 \%\end{array}$

$\begin{array}{lllllll}15 & \text { MJR } & 4 & 3 & 12 & 19 & 5,08 \%\end{array}$

(32b) merumuskan masalah sebagai berikut.

Setelah peneliti mendeskripsikan kesalahan-kesalahan yang mahasiswa lakukan pada makalah mereka, peneliti sajikan tabel distribusi kesalahan untuk $\begin{array}{ccccccc}16 & \mathrm{MF} & 5 & 8 & 9 & 22 & 5,88 \%\end{array}$ $\begin{array}{lllllll}17 & \text { MA } & 2 & 4 & 8 & 14 & 3,74 \%\end{array}$ $\begin{array}{lllllll}18 & \text { PPS } & 1 & 2 & 11 & 14 & 3,74 \%\end{array}$ $\begin{array}{lllllll}19 & \mathrm{RC} & 1 & 5 & 7 & 13 & 3,48 \%\end{array}$ memudahkan perhitungan frekuensi kesalahan.

Tabel 1. Distribusi Kesalahan Ejaan

\begin{tabular}{|c|}
\hline F \\
\hline
\end{tabular}


Dilihat dari tabel frekuensi kesalahan di atas, dari 25 makalah yang dianalisis dalam penelitian ditemukan 374 data kesalahan. Kesalahan penggunaan tanda baca sebanyak 74 (20\%), meliputi kesalahan pemakaian tanda titik (.) sebanyak $43(11,5 \%)$ dan kesalahan pemakaian tanda koma (,) sebanyak $31(8,29 \%)$. Kesalahan pemakaian huruf sebanyak 108 (29\%), meliputi kesalahan pemakaian huruf kapital sebanyak $86(23 \%)$ dan kesalahan pemakaian huruf miring sebanyak 22 (2,9\%). Kesalahan penulisan kata sebanyak 192 (51,33\%), meliputi kesalahan penulisan kata dasar sebanyak 130 (34,76\%), kesalahan penulisan kata berimbuhan sebanyak 46 (12,30\%), dan kesalahan penulisan kata depan sebanyak 16 $(4,28 \%)$.

Dari hasil analisis di atas dapat dilihat bahwa kesalahan penulisan kata dasar mempunyai frekuensi yang paling besar yaitu sebanyak 130 data kesalahan atau 34,76\%. Hal ini menunjukan bahwa mahasiswa masih belum teliti dalam menuliskan sebuah kata. Mereka menuliskan sebuah kata dengan tidak lengkap atau kelebihan huruf.

Sementara itu, yang mempunyai frekuensi kesalahan paling rendah adalah pemakaian kata depan yaitu sebanyak 16 data kesalahan atau 4,28\%. Mahasiswa masih sering keliru dalam penulisan kata depan yang seharusnya terpisah dari kata yang mengikutinya.

Penulis merasa harus lebih meningkatkan kedisiplinan dalam penulisan makalah terutama mengenai Ejaan Bahasa Indonesia (EBI). Mahasiswa masih sering lupa untuk berpedoman pada Pedoman Ejaan Bahasa Indonesia (PUEBI) dalam membuat makalah sehingga kesalahan-kesalahan tersebut tidak bisa dihindari dan jumlahnya masih sangat banyak.

\section{PENUTUP}

Berdasarkan uraian hasil dan pembahasan di atas, penulis dapat menyimpulkan bahwa terdapat beberapa kesalahan penggunaan ejaan dalam makalah mahasiswa. Kesalahan itu meliputi: kesalahan dalam pemakaian tanda baca; kesalahan pemakaian huruf; dan kesalahan penulisan kata.

Kesalahan dalam pemakaian tanda baca meliputi kesalahan pemakaian tanda titik (.) dan pemakaian tanda koma (,). Berikutnya adalah kesalahan pemakaian huruf meliputi kesalahan pemakaian huruf kapital dan huruf miring. Terakhir yaitu kesalahan penulisan kata yang meliputi penulisan kata dasar, 
BAHTERA INDONESIA:

Jurnal Penelitian Pendidikan Bahasa dan Sastra Indonesia
ISSN 2541-3252

Vol. 5, No. 1, Mar. 2020 pemakaian kata berimbuhan, dan pemakaian kata depan.

Melihat frekuensi kesalahan ternyata kesalahan penggunaan ejaan dalam makalah mahasiswa ini merupakan kesalahan yang serius mengingat terdapat jumlah kesalahan sebanyak 374 data dan sangat perlu mendapat perhatian. Hal ini menggambarkan bahwa mahasiswa belum memahami dan masih perlu mendapat bimbingan intensif mengenai Ejaan Bahasa Indonesia baik dari segi kaidah maupun penerapannya.

\section{DAFTAR PUSTAKA}

Fajarya, Nurul dan Azhar Umar, M.Pd. 2016. Analisis Kesalahan Penggunaan Ejaan dalam Karangan Narasi Siswa Kelas X SMA Swasta Taman Siswa Binjai Tahun Pembelajaran 2016/2017. [Online] tersedia dalam https://media.neliti.com/media/publ ications/54031-ID-analisis-

kesalahan-penggunaan-ejaandala.pdf

Fransiska, Maria dan Ikha Listyarini . 2017. Analisis Kemampuan Penggunaan Ejaan dalam Karangan Narasi Siswa Kelas V SDN Tlogongsari Kulon 05 Semarang. Jurnal Lingua. Vol.13 No.1 tahun 2017. Hal 68-76.
[Online] tersedia dalam https://journal.unnes.ac.id/nju/index .php/lingua/article/view/8759

Turistiani, Trinil Dwi. 2013. Fitur Kesalahan Penggunaan Ejaan yang Disempurnakan dalam Makalah Mahasiswa. Paramasastra, Jurnal Ilmiah Bahasa Sastra dan Pembelajarannya. Vol. 1, No. 1, September 2013. Hal 61-72. [Online] tersedia dalam https://journal.unesa.ac.id/index.ph $\mathrm{p} /$ paramasastra/article/view/1470/9 $\underline{85}$

Tussoleksha, Rohmah. 2019. Kesalahan Penggunaan Ejaan Bahasa Indonesia pada Makalah Karya Mahasiswa. Aksara Jurnal Bahasa dan Sastra. Vol.20. No 1. Hal 3543. April 2019. [Online] tersedia dalam http://jurnal.fkip.unila.ac.id/index.php/aks ara/article/view/17810/12714

Sugiyono. 2013. Metode Penelitian Kuantitif, Kualitatif, dan $R \& D$. Bandung:Alfabeta.

Sunardin. 2017. Kesalahan Penggunaan Ejaan Pada Papan Informasi di Rumah Sakit dr.Wahidin Sudirohusodo. [Online] http://digilib.unhas.ac.id/uploaded_files/te mporary/DigitalCollection/OWExNWM2 MTgzMDU1YmFmMGQwYTk5NDJkZj cxMmNmNGIyMWY1MDQ3MA==.pdf 